\title{
A SOLAR DISTILLER PERFORMANCE OF A THIN LAYER FLOW OF BRINE
}

\author{
Ragab, I.A.M. ${ }^{1}$ and H.S. Abdel-Galil ${ }^{2}$
}

\begin{abstract}
A thin layer flow of brine solar distiller model with an inclined movable black solar steel collector was designed and constructed to desalinate sea-water. The range of distiller productivity was about 5 to $8 \mathrm{~L} / \mathrm{m}^{2}$.day, at the operation conditions of (solar radiation of 552.1 to $591.2 \mathrm{~W} / \mathrm{m}^{2}$, ambient temperature of 25 to $31.8^{\circ} \mathrm{C}$, temperature difference between the solar collector \& glass cover of 39 to $52{ }^{\circ} \mathrm{C}$, brine flow rate of 4 to 10 L/hr and finally, solar collector angle of $15^{\circ}$ to $45^{\circ}$ to the horizontal). Step-wise regression analysis was applied to get the best set of the statistical model on distillated water productivity. The determination of correlation of the final model was 0.97. Also, the operational efficiency was calculated, which ranged from 53 to $63 \%$.
\end{abstract}

\section{INTRODUCTION}

I

$\mathrm{t}$ has already been established that, a reduction in the depth of brine in the basin of the roof-type solar distiller improves the distillated water productivity. This conclusion led Frick \& Sommerfeld (1973) to design a wick-type collector-evaporator distiller. The advantage of the wick is to keep the basin as shallow as possible while avoiding dry spots. The results of Frick \& Sommerfeld for a distiller of this type using a plastic cover, located at Valparaiso, Chile showed a production rate of 3.8 to $4.4 \mathrm{~L} / \mathrm{m}^{2}$.day, with an operational efficiency of about 40 to $46 \%$. An improved design for the wick-type collector-evaporator distiller was carried out by Moustafa et al. (1979). The results of his design showed a maximum productivity of 6.5 $\mathrm{L} / \mathrm{m}^{2}$.day, with an operational efficiency of about $58 \%$.

1- Assoc. Prof. of Agric. Eng., Fac. Of Agric., Fayoum Univ.

2- Lect. of Agric. Eng., Fac. Of Agric., Fayoum Univ. 
Numerous publications of basin type solar distiller were found in the literatures e.g.(Ragab \& Zine El-Abedin, 20o6; Ragab, 2006; Ragab \& Abou-Karima, 2005; Ragab, 2005; Minasian et al., 1992; Kudish, 1991; Kudish \& Gale, 1986; Richared et al., 1984; Malik et al., 1982; Kudish et al., 1982; and Delyannis \& Delyannis, 1980).

Ernani, (1996) studied a solar still versus solar evaporator (a comparative study between their thermal behavior). He concluded that, the distillation rate increases with increasing water temperature and temperature differences. Harpreet, (1996) simulated a computer program of a solar distiller with enlarged evaporation area, in order to explore the quantitative relationship between

evaporation area and distillation yield. Shukla \& Sorayan, (2005) derived a mathematical expiration for water and glass temperatures, yield and efficiency for a single and double slopes multi-wick solar distiller in the steady conditions.

This research was planned to study the performance of a wick-type solar distiller using a glass cover, and evaluating its operational efficiency .

\section{MATERIALS AND METHODS}

\section{1- The experimental setup :-}

The experiments were carried out using a sloped solar distiller model with a movable black solar steel collector (a thin layer of brine with $5 \mathrm{~mm}$ depth at maximum passes on its surface area), which illustrated in Fig.(1). It consisted of a wooden box of $1.18 \times 1.08 \times 0.75 \mathrm{~m}$ and $0.02 \mathrm{~m}$ thickness. A steel box of $1.1 \times 1.0 \times 0.75 \mathrm{~m}$ and $0.5 \mathrm{~mm}$ thickness put inside the wooden box. The fibber isolation of $0.02 \mathrm{~m}$ put between the steel box and the wooden box. A glass cover of $3 \mathrm{~mm}$ thickness fixed over the wooden box. A black steel solar collector with surface area of $1 \mathrm{~m}^{2}$ and $3 \mathrm{~mm}$ thickness hinged under the lower side of the glass cover. The other side of the solar collector was movable for collector angle controlling. This side had a $\mathrm{U}$ channel for brine storing and flowing to passes above the solar collector surface area. An isolation sheet of $0.02 \mathrm{~m}$ thickness was fixed under the steel solar collector to prevent heat lose through its thickness. A steel channel was fitted under the lower side of the glass cover to collect the condensed water, which collected into 
external vessel. Another steel channel was fitted under the hinged solar collector side to collect the exceed brine flow. The wick-type model was inclined at angle of $45^{\circ}$ to horizontal. An external plastic tank of (150 Liters capacity) was put above the distiller model level to supply the wick model by brine water through a plastic pipe. A regulator valve was put at output line of the plastic tank for brine flow rates controlling. All openings in the sides of the distiller model and all joints in glass cover and channels were well sealed with silicon rubber sealant to prevent water vapor leakage. The axis of the wick-type solar distiller model was oriented to face an east-west direction and the sloped side of the distiller was oriented south.

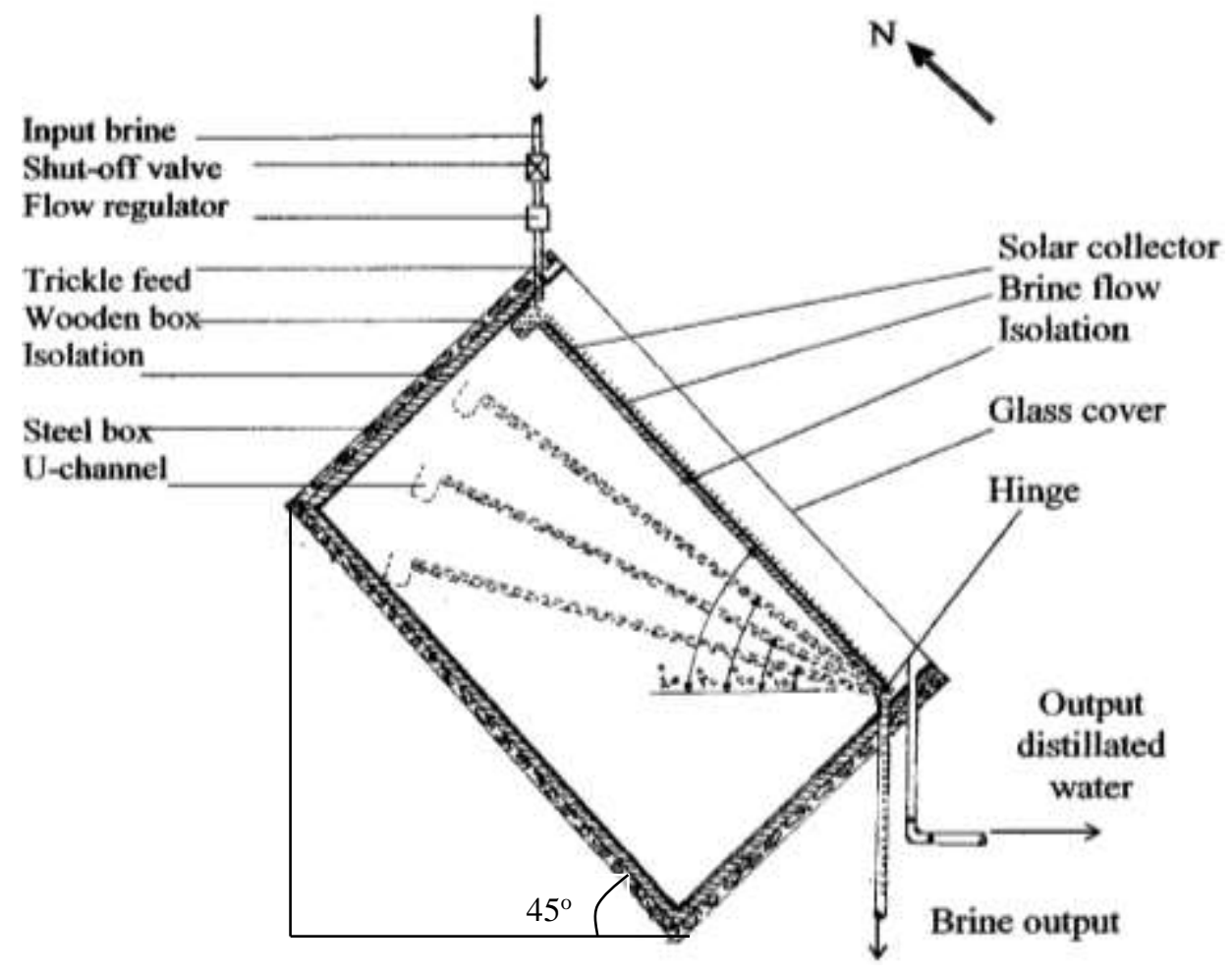

Fig(1): schematic drawing of a solar distiller model of a thin layer flow of brine

Global solar radiation $\left(\mathrm{I}, \mathrm{W} / \mathrm{m}^{2}\right)$, and ambient air temperatures $\left(\mathrm{T}_{\mathrm{a}},{ }^{\circ} \mathrm{C}\right)$ were recorded. The surface area of the solar collector was $1 \mathrm{~m}^{2}$. The value of distillated water $\left(\mathrm{D}_{\mathrm{w}}, \mathrm{L} / \mathrm{m}^{2}\right)$ was measured daily, after sunset. 
Copper constantan thermocouples connected to the system for measuring the collector temperature $\left(\mathrm{T}_{\mathrm{c}},{ }^{\circ} \mathrm{C}\right)$, and temperature of the inner side of the glass cover, $\left(\mathrm{T}_{\mathrm{g}},{ }^{\circ} \mathrm{C}\right)$. A digital thermometer VE310 was used for recording temperatures needed, which has the accuracy of $0.1{ }^{\circ} \mathrm{C}$.

The experimental work was carried out at a location in the North Coast at $\mathrm{km} 20$ of Alexandria-Matrouh road, which is situated about $1.2 \mathrm{~km}$ from the Mediterranean Sea.A salty seawater sample was taken to measure the salinity value and to determine its chemical analysis. The electrical conductivity of the salty water sample was $53.4 \mathrm{mmoh} / \mathrm{cm}(53.4 \mathrm{ds} / \mathrm{m})$ at $25{ }^{\circ} \mathrm{C}$. Table (1) shows the chemical analysis of the seawater sample. This analysis was conducted at a laboratory of Soil and Water Dept., Fac., Agric., Fayoum Univirsity.

Table (1): The chemical analysis of the sea-water sample :

\begin{tabular}{|c|c|c|c|c|c|c|c|c|c|}
\hline \multicolumn{4}{|c|}{ Anions, (meq/l) } & \multicolumn{4}{c|}{ Cations, (meq/l) } & Ec & $\mathrm{PH}$ \\
\cline { 1 - 7 } $\mathrm{SO}_{4}$ & $\mathrm{CL}$ & $\mathrm{HCO}_{3}$ & $\mathrm{CO}_{3}$ & $\mathrm{Mg}$ & $\mathrm{Ca}$ & $\mathrm{K}$ & $\mathrm{Na}$ & & \\
\hline 17.9 & 258.3 & 2.3 & - & 52.6 & 16.2 & 6.8 & 202.7 & 53.4 & 7.6 \\
\hline
\end{tabular}

\section{Operational efficiency of the wick-type solar distiller model :-}

The operational efficiency of a roof solar distiller was driven by Moustafa et al. (1994), and Fernandez \& Chargoy (1990). The final mathematical form are :

$$
\begin{aligned}
& \eta=q_{e} /\left(q_{e}+q_{c}+q_{r}\right) \\
& q_{e}=0.0061\left\{\left(T_{c}-T_{g}\right)+\left[\left(P_{c}-P_{g}\right) /\left(0.265-P_{c}\right)\right] . T_{c}\right\}^{1 / 3} \cdot\left(P_{c}-P_{g}\right) . L_{c} \ldots . . \\
& q_{c}=0.8831\left\{\left(T_{c}-T_{g}\right)+\left[\left(P_{c}-P_{g}\right) /\left(0.265-P_{c}\right)\right] \cdot T_{c}\right\}^{1 / 3} \cdot\left(T_{c}-T_{g}\right) \\
& \mathbf{q}_{\mathrm{e}}=f_{\mathrm{cg}} \cdot \sigma \cdot\left(\mathbf{T}_{\mathrm{c}}{ }^{4}-\mathbf{T}_{\mathrm{g}}{ }^{4}\right)
\end{aligned}
$$

where ;

$\eta$ is the distiller operation efficiency in, $\%$,

$\mathrm{q}_{\mathrm{e}}$ is the rate of heat flux transferred by evaporation between water surface and distiller cover in, $\mathrm{W} / \mathrm{m}^{2}$,

$\mathrm{q}_{\mathrm{r}}$ is the rate of heat flux transferred by radiation between water surface and distiller cover in, $\mathrm{W} / \mathrm{m}^{2}$,

$\mathrm{q}_{\mathrm{c}}$ is the rate of heat flux transferred by convection between water surface and distiller cover in, $\mathrm{W} / \mathrm{m}^{2}$,

$\mathrm{Tc}$ is the collector surface temperature in, ${ }^{\circ} \mathrm{C}$, 
$\mathrm{Tg}$ is the glass cover temperature inside the distiller in, ${ }^{\circ} \mathrm{C}$,

$\mathrm{Pc}$ is the saturation pressure of water at $\mathrm{T}_{\mathrm{c}}$ in, Mpa,

$$
\mathbf{P}_{\mathbf{c}}=\exp \left\{25.317-\left(5144 / \mathrm{T}_{\mathbf{c}}\right)\right\}
$$

$\mathrm{P}_{\mathrm{g}}$ is the saturation pressure of water at $\mathrm{T}_{\mathrm{g}}$ in $\mathrm{Mpa}$,

$$
P_{g}=\exp \left\{25.317-\left(5144 / T_{g}\right)\right\}
$$

$\mathrm{L}_{\mathrm{c}}$ is the inner latent heat of brine at $\mathrm{T}_{\mathrm{c}}$ in, $\mathrm{J} / \mathrm{kg}$,

$$
\mathbf{L}_{\mathbf{c}}=\left(\mathbf{2 5 0 1 . 6 7 - 2 . 3 8 9} \mathbf{T}_{\mathrm{c}}\right) .10^{3}
$$

$\sigma$ is the Stefen-Boltzman constant $=56.7 \times 10^{-9} \mathrm{~W} / \mathrm{m}^{2} \cdot \mathrm{k}^{4}$

$f_{\mathrm{cg}}$ is the shape factor of diffuse radiation between collector and cover, dimensionless,

$$
f_{\mathrm{cg}}=1 /\left\{1 / \varepsilon_{\mathrm{c}}+1 / \varepsilon_{\mathrm{g}}-1\right\}
$$

$\boldsymbol{\varepsilon}_{\mathrm{c}}$ is the collector emmissivity (infrared), $\boldsymbol{\varepsilon}_{\mathrm{g}}$ is the glass emmissivity (infrared), $\boldsymbol{\varepsilon}_{\mathbf{c}}=0.88$ and $\boldsymbol{\varepsilon}_{\mathbf{g}}=0.9$ (Clark, 1990).

Note: brine temperature over the solar collector, $\mathrm{T}_{\mathrm{w}}$ is approximately equal $\mathrm{Tc}$, where, the brine depth is very thin.

\section{RESULTS AND DISCUSSION}

Experimental work was carried out through August, September, October and November. The averages of metrological data were as following ; solar radiation intensity ranged from 552.1 to $590 \mathrm{~W} / \mathrm{m}^{2}$; ambient air temperature ranged from 25 to $29.8{ }^{\circ} \mathrm{C}$; wind speed ranged from 4.7 to 15 $\mathrm{km} / \mathrm{hr}$ and the relative humidity was about $64 \%$ ).

\section{1- Effect of solar radiation intensity on distillated water productivity:}

The most important parameter affecting the performance of a solar distiller is the solar radiation intensity. The distillated water productivity increases as solar radiation intensity increases and vice versa, as indicated at Fig. (2).

An equation was developed by Excel-2003 soft-ware, which has a formula of;

$$
D_{w}=6 \text { E-15 } I^{5.4596} \quad R^{2}=0.90 .
$$

Where, $D_{w}$ is the distillated water productivity in, $L / \mathrm{m}^{2}$.day, and $\mathrm{I}$ is the solar radiation intensity in $\mathrm{W} / \mathrm{m}^{2}$. 


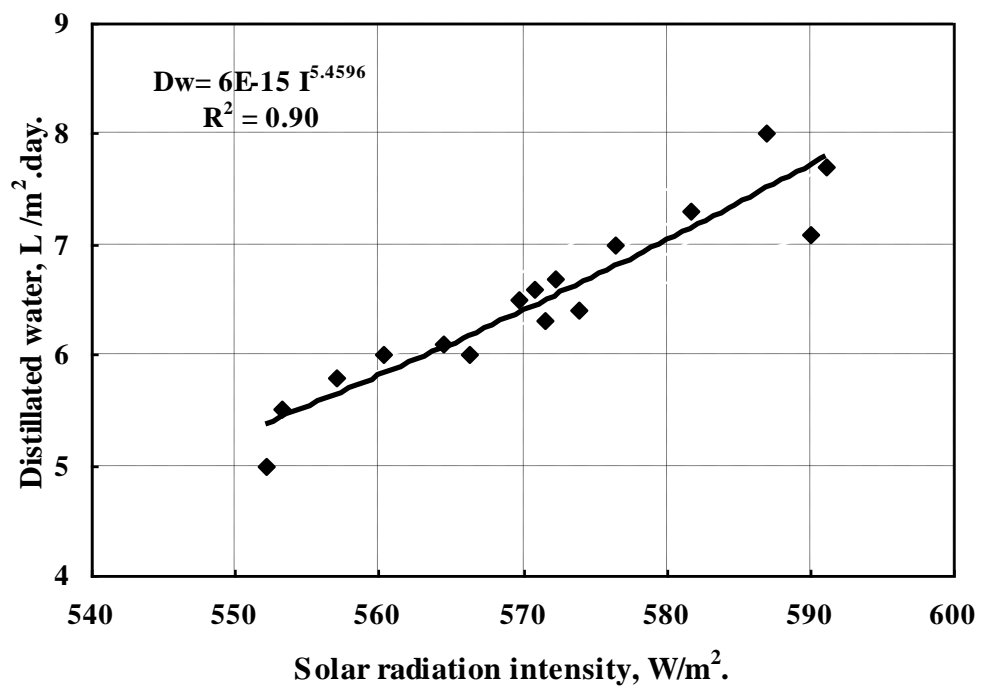

Fig. (2): Effet of solar radiation intenisty on distillated water productivity

2- Effect of brine flow rates and solar collector angles on both of temperatures difference between solar collector \& glass cover and solar distiller efficiency:

Figs.(3a, b, c \& d) show the effect of brine flow rates on temperatures difference between solar collector and glass cover and on a flow of a thin layer of brine solar distiller efficiency at different levels of solar collector angles. In general, there is an increasing in solar distiller efficiency with decreasing of brine flow rates. Also, there is a decreasing of temperatures difference between solar collector and glass cover, with increasing of brine flow rates, and vice versa. The best results are noticed at solar collector angle $(\theta)$ of $25^{\circ}$, where the temperature difference $(\Delta \mathrm{T})$ ranged from $45{ }^{\circ} \mathrm{C}$ to $52{ }^{\circ} \mathrm{C}$ and the distiller efficiency $(\eta)$ ranged from $59 \%$ to $63 \%$ as brine flow rate $(\mathcal{F})$ ranges decreased from $10 \mathrm{~L} / \mathrm{hr}$ to $4 \mathrm{~L} / \mathrm{hr}$. 


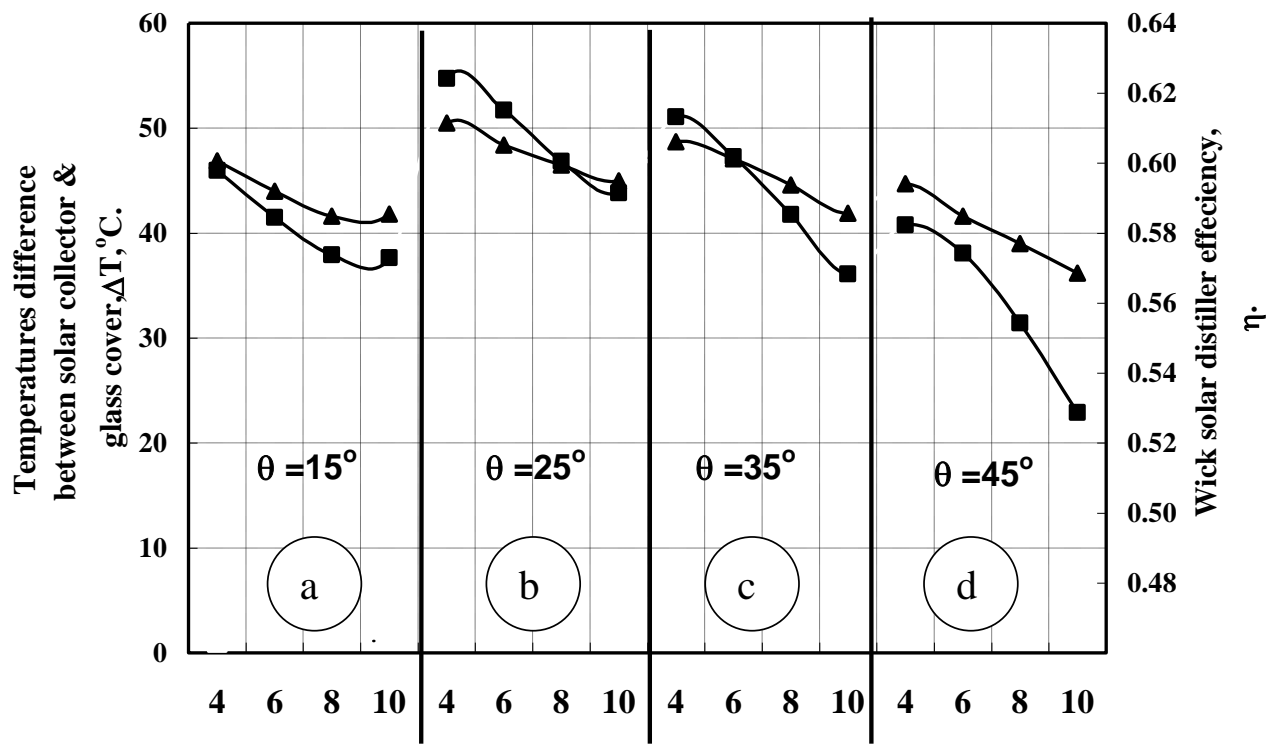

Brine flow rate $(F), \mathrm{L} / \mathrm{hr}$.

Fig. (3): Effect of collector angle $\&$ brine flow rate on both of temperatures difference between sthe solar collector $\&$ the glass cover and distiller model effeciency

$\rightarrow$ Distiller effeciency

Fig.(4) shows the effect of solar collector angles on distillated water output at different levels of brine flow rates. It is indicated that, the collector angle of $25^{\circ}$ is the optimum degree, where, it has a maximum productivity of distillated water. Also, the minimum productivity is given by $45^{\circ}$ of collector angle and $10 \mathrm{~L} / \mathrm{hr}$ of brine flow rate. Fig. (4) shows that, the productivity of distillated water increases as brine flow rates decrease.

\section{3- Effect of temperatures difference between solar collector \& glass} cover on both of a solar distiller productivity and efficiency:

As noticed at Fig.(4), that both of distiller productivity and efficiency increase with temperatures difference between solar collector and glass cover increases.

The following equations were resulted by Excel-2003 soft-ware for estimating the distiller productivity $\left(D_{w}\right)$ and distiller efficiency $(\eta)$.

$$
\begin{aligned}
& D_{w}=0.0066 \Delta T^{1.8117} \\
& \eta=0.0591 \Delta T^{0.6032}
\end{aligned}
$$$$
\mathbf{R}^{2}=\mathbf{0 . 9 2}
$$$$
R^{2}=0.94
$$ 


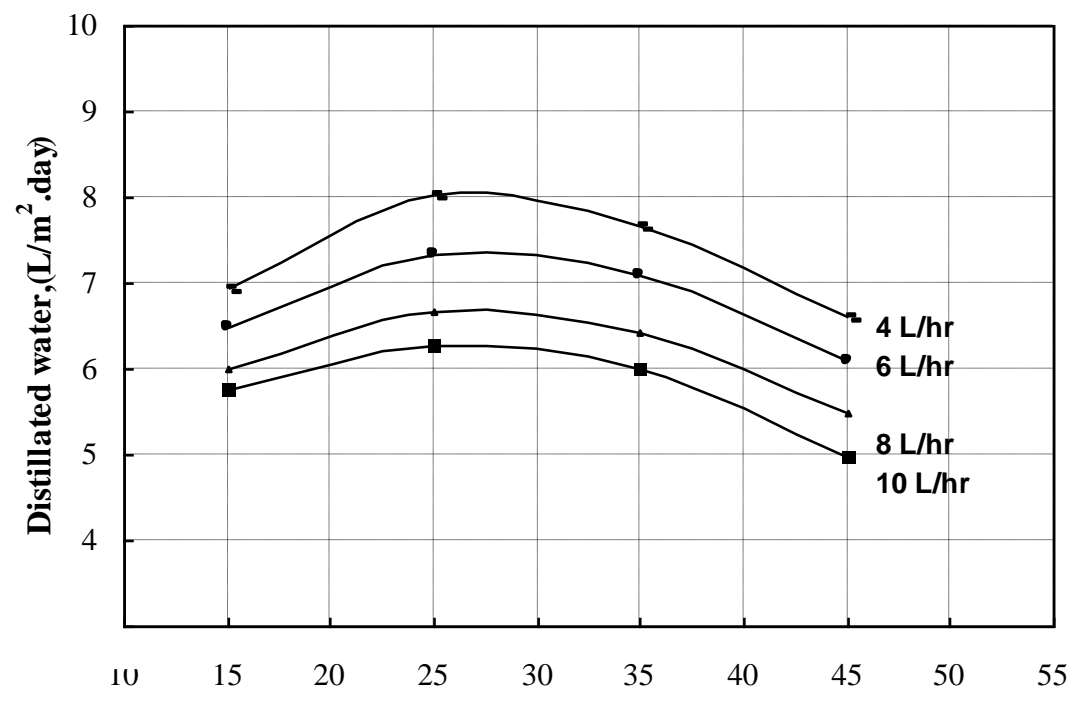

Collector angle, (degree)

Fig.(4): Effect of solar collector angle on distillated water at different brine flow rates.

Where, $\Delta \mathrm{T}$ is the temperatures difference between solar collector and glass cover in, ${ }^{\circ} \mathrm{C}$, and $\eta$ is the solar distiller efficiency in, $\%$.

\section{4- Effect of temperatures difference between solar collector and glass cover on saturation pressure difference between brine $\&$ glass cover and distillated water:}

It is known that, the more the difference between saturation pressure of water at solar collector $\left(\mathrm{P}_{\mathrm{c}}\right)$ and saturation pressure of water at glass cover $\left(\mathrm{P}_{\mathrm{g}}\right)$ the greater the vapor condensed and the higher the water evaporate and escape from water surface to face the cold glass cover and condensed on it. This was the direct reason in increasing the distillation rates. Fig. (5) shows that, pressures difference increases as temperature difference between brine and glass cover increases. Also, It is clear that, 


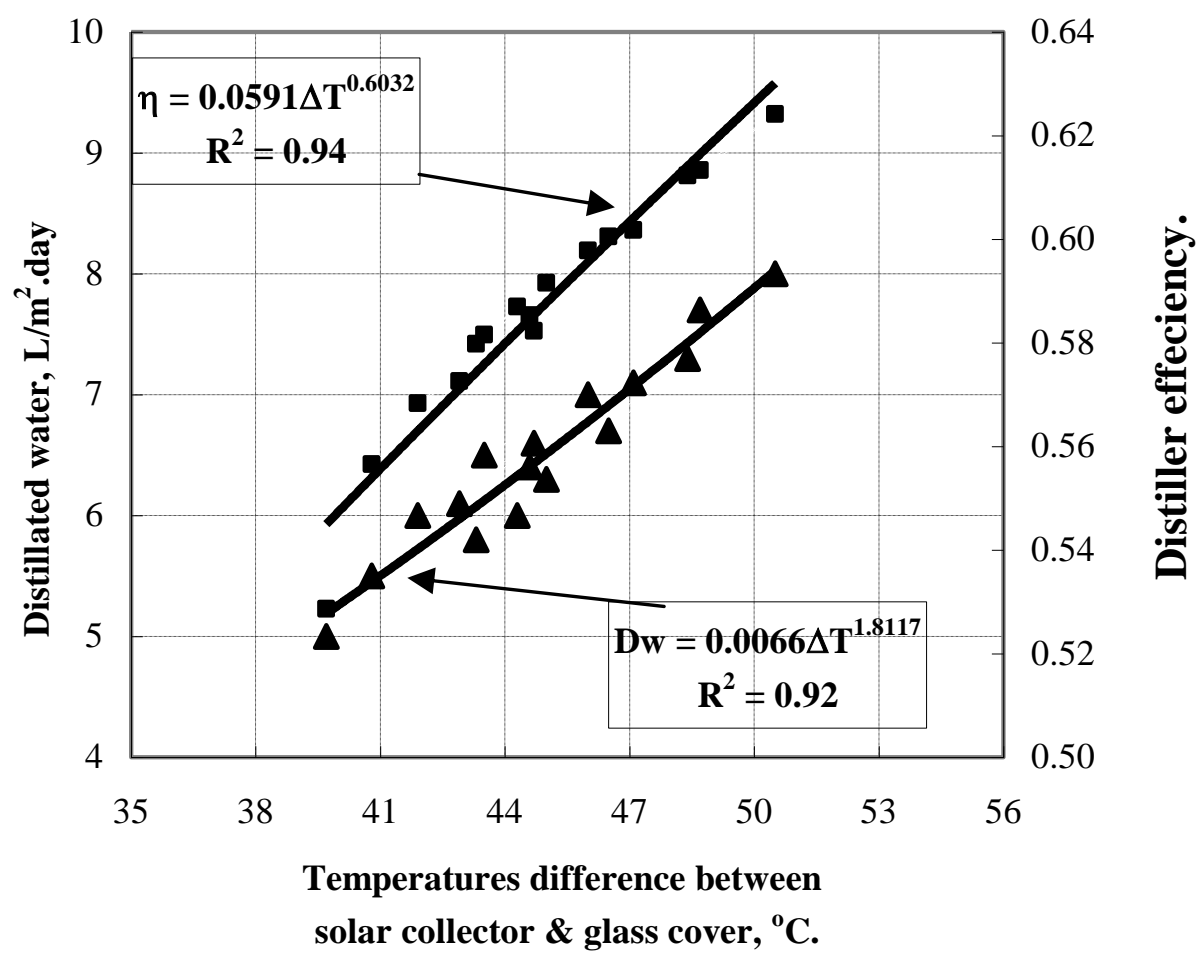

Fig.(4): Effect of temperatures difference between solar collector \& glass cover on both of distillated water and distiller effecincy

as saturation pressure difference between the solar collector and the glass cover increases, the distillated water productivity increases. Excel-2003 soft-ware was used to develop the best fit of data. An exponential equation was resulted as following;

$$
\Delta P=0.2719 \Delta T^{1.3435} \quad R^{2}=0.82 .
$$

Where, $\Delta \mathrm{P}$ is the saturation pressure difference between the solar collector $\left(\mathrm{P}_{\mathrm{c}}\right)$ and the glass cover $\left(\mathrm{P}_{\mathrm{g}}\right)$ in $\mathrm{MPa}$. 


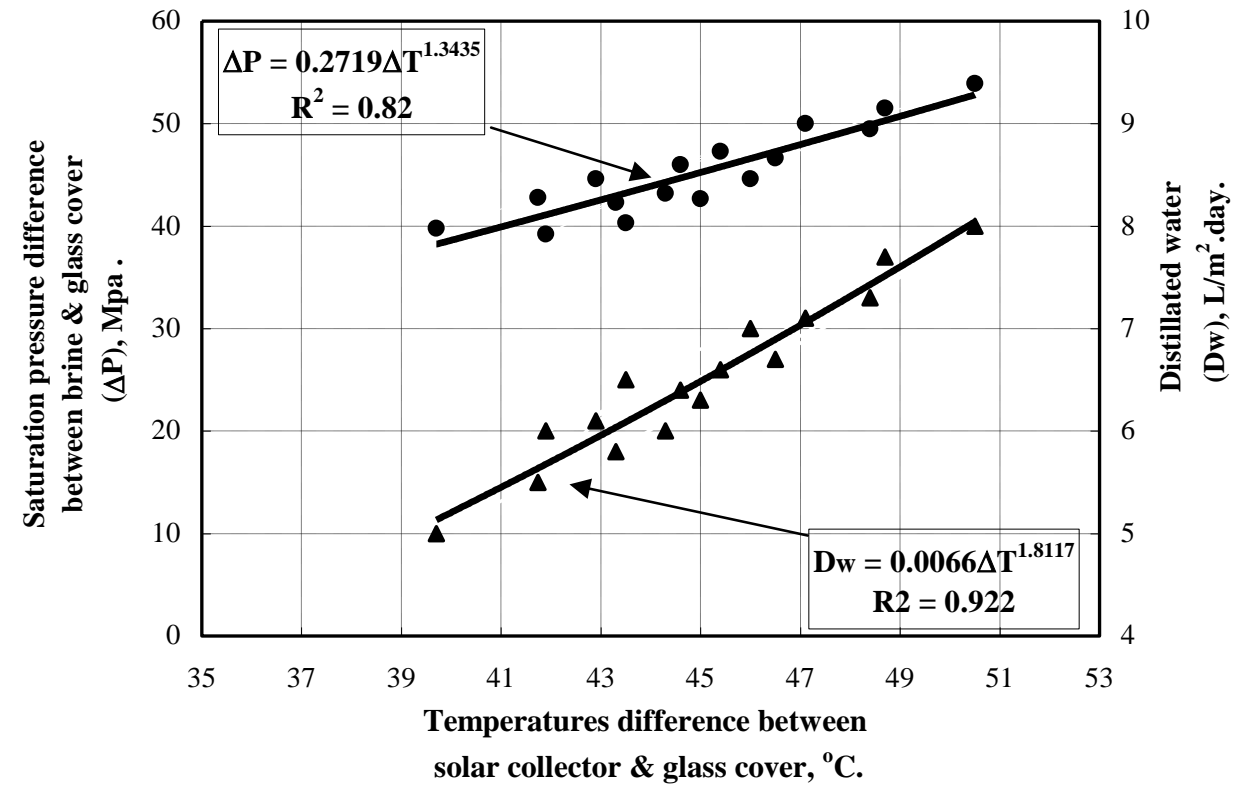

Fig.(5): Effect of temperatures difference between solar collector \& glass cover on both of distillated water and saturatio pressure difference between brine water $\&$ glass cover.

\section{5- Effect of temperatures difference between solar collector and glass cover on rate of heat flux transferred by evaporation and distillated water:}

Fig.(6) shows that, as temperatures difference increases the rate of heat flux transferred by evaporation increases. So that, increasing of the rate of heat flux transferred by evaporation cased to increase the distillated water as, shown in Fig. (6). An exponential equation was resulted by Excel-2003 statistical software as follows:

$$
\mathrm{qe}=12.57 \Delta \mathrm{T}^{1.4331} \quad \mathrm{R}^{2}=\mathbf{0 . 8 1}
$$

where, qe is the rate of heat flux transferred by evaporation between the brine surface and the glass cover in, $\mathrm{W} / \mathrm{m}^{2}$. 


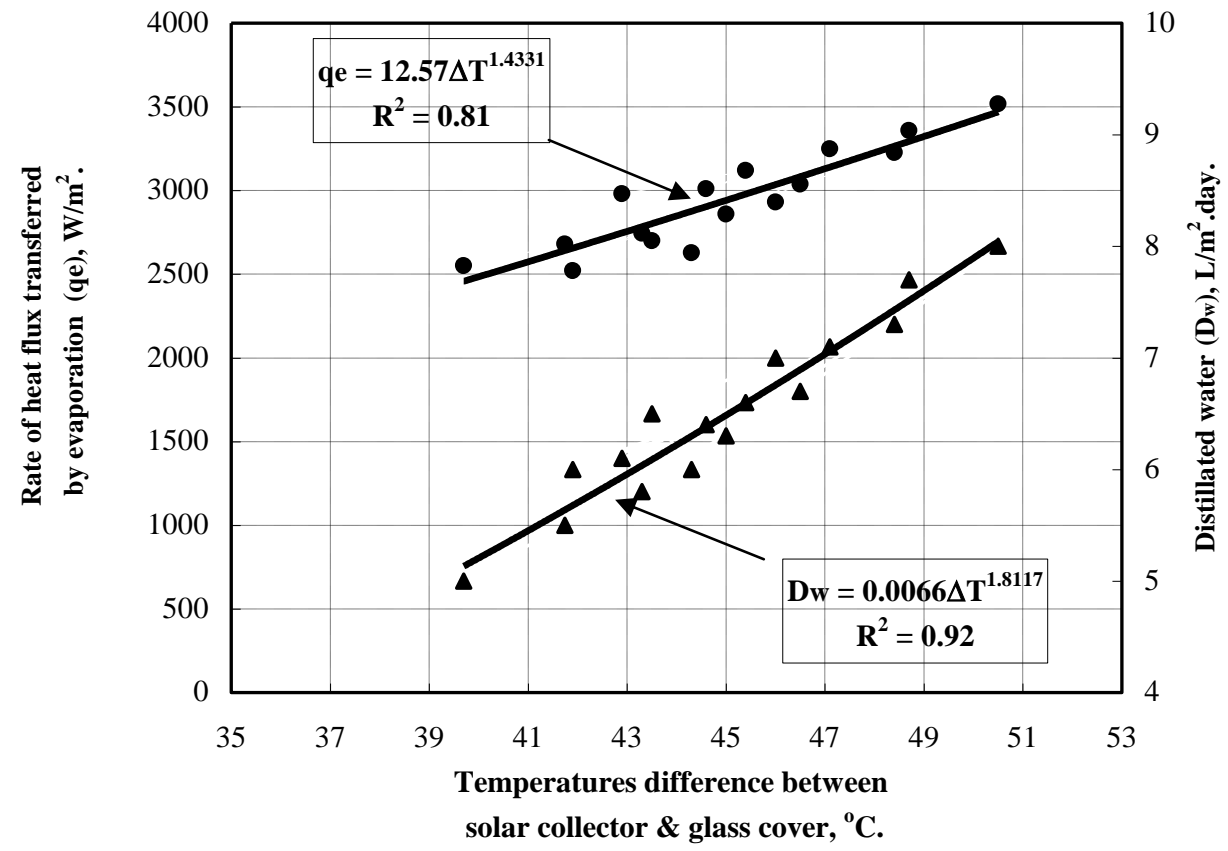

Fig.(6): Effect of temperatures difference between solar collector \& glass cover on both of distillated water and the rate of heat flux transferred by evaporation.

\section{5- The statistical analysis evaluation:}

The forward step-wise regression analysis was applied to arrive at a reasonably good best set of independent variables (solar radiation intensity $\left(\mathrm{I}, \mathrm{W} / \mathrm{m}^{2}\right)$, Ambient air temperature $\left(\mathrm{T}_{\mathrm{a}},{ }^{\circ} \mathrm{C}\right)$, temperatures difference between the solar collector and the glass cover $\left(\Delta \mathrm{T},{ }^{\circ} \mathrm{C}\right)$, brine flow rates $(F, \mathrm{~L} / \mathrm{hr})$ and solar collector angle $(\theta$, degree), relating to distillated water productivity $\left(\mathrm{D}_{\mathrm{w}}, \mathrm{L} / \mathrm{m}^{2}\right.$.day). The suggested statistical model was in form of ;

Dw $\alpha(\mathbf{I}, \Delta \mathbf{T}, \mathbf{T a}, \theta, F)$

The final statistical model form is ;

$$
D_{w}=-8.971+0.1687 \Delta T-0.07 F+0.0147 I \quad R^{2}=0.97 \ldots \ldots(13)
$$


The forward step-wise technique indicated that, $\Delta \mathrm{T}$ is the important parameter affecting on $D_{w}$, see Table (2). The resulted statistical model has shown to be significant at 0.001 level.

Fig.(6) shows the graph of $45^{\circ}$ for predicted and observed data of the distillated water productivity. the correlation coefficient $R^{2}=0.97$.

Table (2): Summary of forward selection procedure for dependent variable $\mathrm{Dw}_{\mathrm{w}}$.

\begin{tabular}{|l|l|l|c|c|l|}
\hline Step & $\begin{array}{l}\text { Variable } \\
\text { Entered }\end{array}$ & $\begin{array}{c}\text { Number } \\
\text { In }\end{array}$ & $\begin{array}{c}\text { Partial } \\
\mathrm{R}^{2}\end{array}$ & $\begin{array}{c}\text { Model } \\
\mathrm{R}^{2}\end{array}$ & Prob $>\mathrm{F}$ \\
\hline 1 & $\Delta \mathrm{T}$ & 1 & 0.9004 & 0.9004 & 0.0001 \\
2 & $\boldsymbol{F}$ & 2 & 0.0437 & 0.9441 & 0.0023 \\
3 & $\mathrm{I}$ & 3 & 0.0265 & 0.9706 & 0.0047 \\
4 & $\mathrm{Ta}$ & 4 & 0.0023 & 0.9729 & 0.1656 \\
5 & $\theta$ & 5 & 0.0004 & 0.9733 & 0.2354 \\
\hline
\end{tabular}

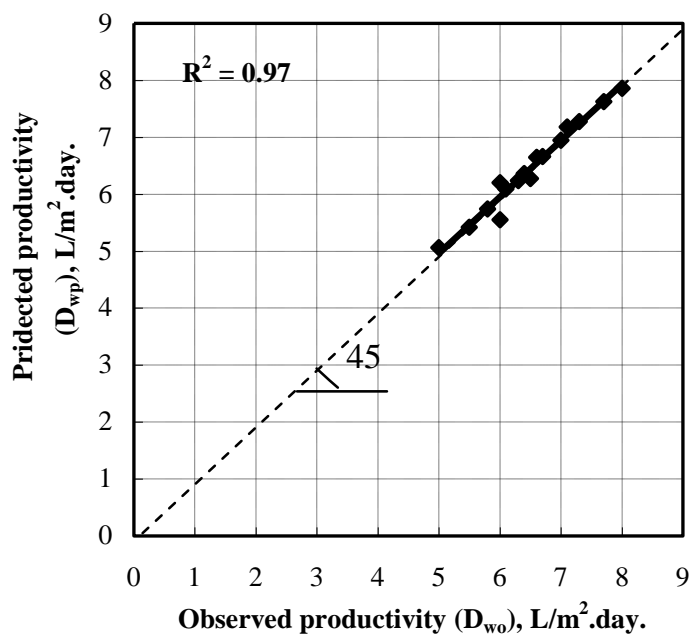

Fig.(6): Observed distillated water productivity vs. predicted productivity

\section{CONCLUSION}

1- The parameters of a solar distiller model of a thin layer flow of brine caused increasing the distillated water from 5 to $8 \mathrm{~L} / \mathrm{m}^{2}$.day, and increasing the distiller efficiency from $53 \%$ to $63 \%$.

2 - There is no direct effect of solar collector angle on productivity water, 
but there is indirect effect. While, the solar collector angle effect on the temperatures difference between the collector and the glass cover by changing the space between the solar collector and the glass cover, e.g, $45^{\circ}$ of solar collector angle caused an increasing of $\mathrm{Tg}, \quad \square \square \square$ so, $\Delta \mathrm{T}$ and $\mathrm{D}_{\mathrm{w}}$ decreased. On the other hand, a solar collector angle of $15^{\circ}$ to horizontal caused decreasing of $\mathrm{T}_{\mathrm{c}}$, so $\Delta \mathrm{T}$ and $\mathrm{D}_{\mathrm{w}}$ decreased.

3 - there is an interaction between the collector angles and brine flow rates, where, the collector angle effect on brine velocity and brine temperature.

\section{REFERENCESES}

Clark, J.A. (1990). The steady state performance of solar still. Solar Energy, 44(3): 43-49.

Delyannis, A. and Delyannis, E.E. (1980). Sea water and desalting. Spring. Berlin, Vol.(1), P. 188.

Ernani, S. (1996). Solar still versus solar evaporator : A comporative study between their thermal behaviors. Solar Energy, 56(2): 199 $-206$.

Fernandez, J.L. and N. Chargoy (1990). Multi-stage indirectly heated Still. Solar Energy, 44(4): 215-223.

Frick, G. and J.V. Sommerfeld (1973). Solar stills of inclined evaporating cloth. Solar Energy, 14:427-431.

Harpreet, S.K. (1996). Performance of solar still: Predicted effect of enhanced evaporation area on yield and evaporation temperature. Solar Energy, 56(3): 261-266.

Kudish, A.I. (1991). Water desalination. Solar Energy in AgricultureEnergy in World Agriculture. Parker B.F. (Ed), Elsevier, Amsterdam, 4(8): pp. 255-294.

Kudish, A.I. and J. Gale (1986). Solar desalination in conjunction with controlled environment agriculture. Energy Conservation and Management, 26, 201.

Kudish, A.I., J. Gale and Y. Zarmi (1982). A low cost design solar Desalination unit. Energy Conservationand Management, 22,269. Malik, M.A.S.; G.N. Tiwari; A. Kumar and M.S. Sodha (1982). Solar distillation. Pergameon Oxford, P. 175.

Minasian A.N., A.A. Al-Karaghouli, M. Hasan and A. Shakir (1992). Utilization of solar earh-water stills for desalination of groundwater. Solar Energy, 49(2): 107-110.

Moustafa, M. E., S.T. Ibrahim and A.S. Jaffar (1994). Design of solar 
thermal systems. $1^{\text {st }}$ d. $1414 \mathrm{AH}$.

Moustafam S.M.A. and G.H. Brusewitz (1979). Direct use of solar energy for water desalination. Solar Energy, 22(3): 141.

Ragab, I.A.M. (2006). Performance of solar still model under the climatic conditions of the newly reclaimed soils. Alex. Sci. Exch. J, 27(2):163169 .

Ragab, I.A.M. (2005). Solar extraction of soil moisture. Misr. J. Ag. Eng. 22(2):351-362 .

Ragab, A.I.M. and T.K. Zin El-Abdin (2006). Modification and simulation of solar earth-water still. Alex. J. Ag. Res., 51(3):1-6.

Ragab, I.A.M. and A.M. Aboukarima (2005). Solar distillation of ground water under Fayoum climatic conditions. Misr. J. Ag. Eng., 22(2):635-645.

Richard, C.P. ; T.M. Skergan and D.B. Marx (1984). Solar earth-water distillation for wet sand. Trans. ASAE, 1690-1695.

Shukla, S.K. and V.P.S. Sorayan (2005). Thermal modeling of solar stills: an experimental validation. Renwabl Energy, 30:683-699.

الملخص العربي

أداء مقطر شمسي ذو سريان لطبقة رقيقة من المياه المالحة

رجب إسماعيل أحمد مراد' حمدي السيد سالم عبد الجليل'

أجريت هذه الدراسة بغرض تقيم أداء مقطر للمباه المالحة ، يستمد طاقته مباشرة من الأشعة

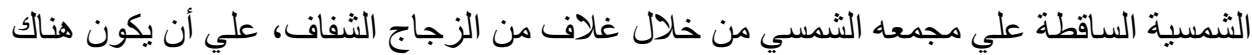

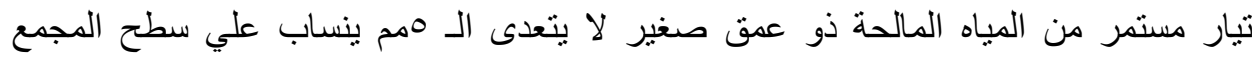

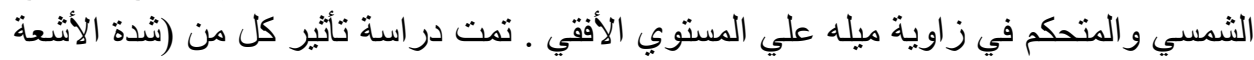

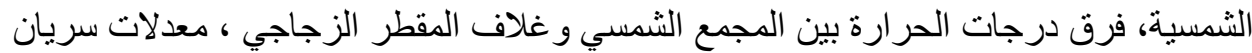

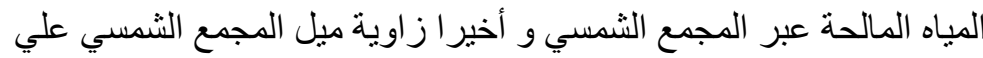

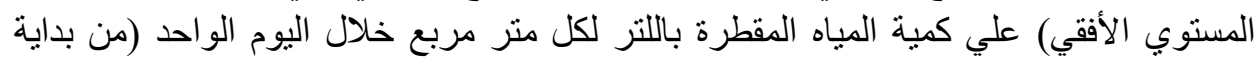

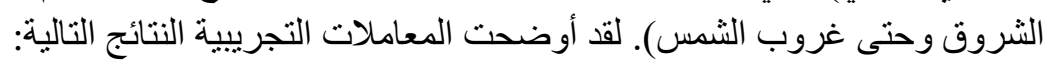

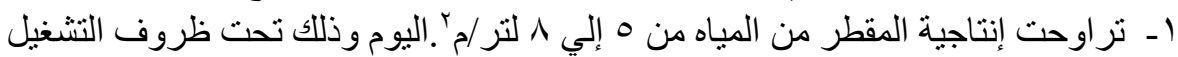

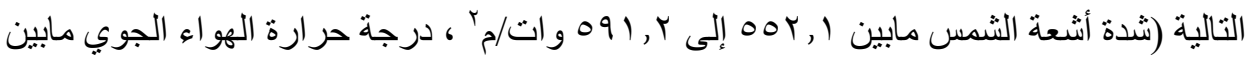

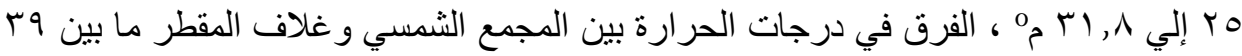

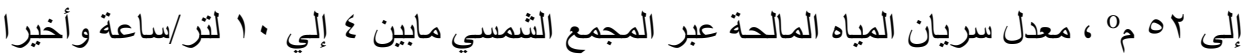

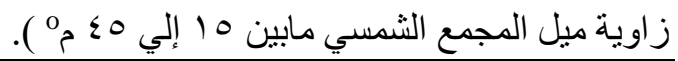

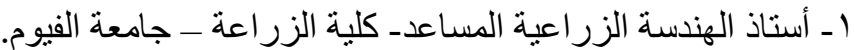


r - مدرس الهندسة الزر اعية ـ كلية الزر اعة - جامعة الفيوم .

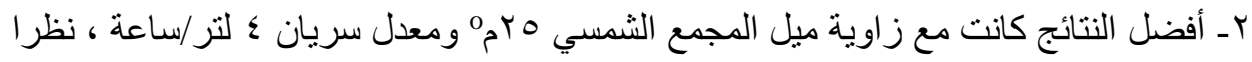

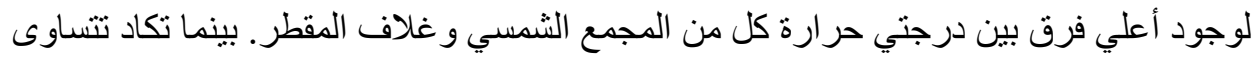

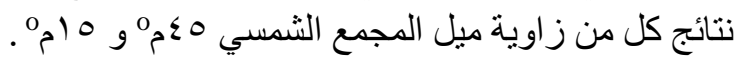

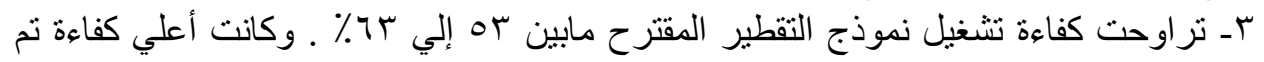

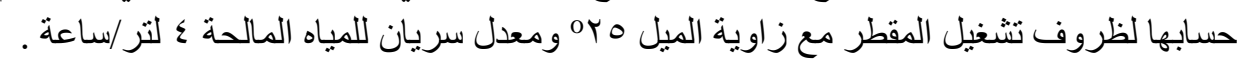

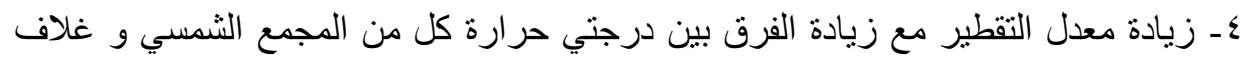

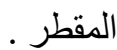

هـ زيادة معدل التقطير مع زيادة الفرق بين ضغطي التشبع لبخار الماء عند كل من المجمع

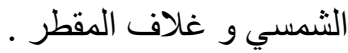

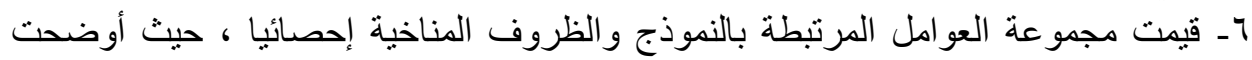

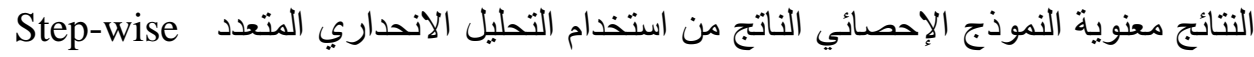

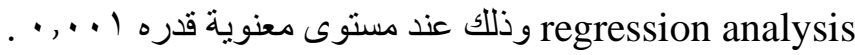

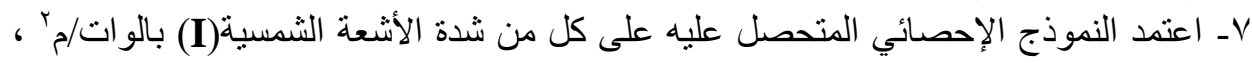

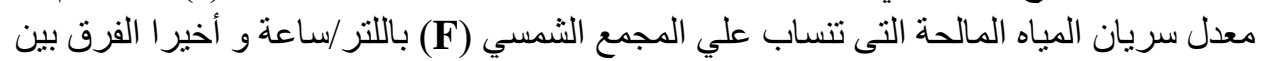

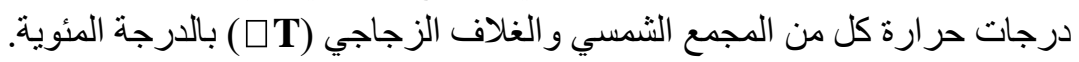

\section{$\left(D_{w}=-8.971+0.1687 \square T-0.07 F+0.0147 I\right)$}

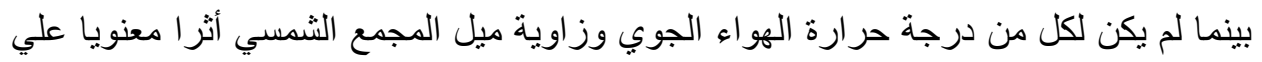

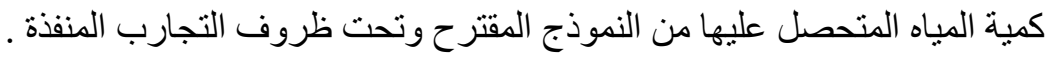

